\title{
PRICE-SUPPLY FLEXIBILITY OF WHEAT MARKET IN THE CZECH REPUBLIC
}

\author{
Pavel Syrovátka
}

\author{
Received: April 11, 2013
}

\begin{abstract}
SYROVÁTKA PAVEL: Price-supply flexibility of wheat market in the Czech Republic. Acta Universitatis Agriculturae et Silviculturae Mendelianae Brunensis, 2013, LXI, No. 4, pp. 1145-1151

The paper explores of the price-supply flexibility of the Czech commodity market for food quality wheat in the period 1995-2011. For this analysis, inversion definition of the supply function was applied. The model of the inverse supply function in the Czech wheat market was based on the double log-linear construction. The parameters of the given supply model were estimated using OLS-HAC method. The developed regression model of the supply function was statistically tested. Ordinary and dynamic price flexibility of the wheat supply on the Czech commodity market was determined in relation to the parameters of the developed econometric model. In accordance with the estimations, the ordinary price-supply flexibility achieved $+0.3492 \%$ and the dynamic price-supply flexibility of the first order was $-0.2210 \%$. Within the interpretation of both estimated coefficients of the pricesupply flexibility, the multi-factor nature of the commodity supply function must be respected. Moreover, it is important to distinguish the short-term and long-term period within the evaluation of the price-supply flexibility.
\end{abstract}

Czech wheat market, agricultural commodity supply, inverse supply function, regression supply model, price-supply flexibility

For the quantitative-economic analyses of the commodity verticals, the development and formulation of the econometrical models of the market demand and supply functions is a very important phase, see Adams and Behrman, (1976) or later Cramer and Jensen (1994). In the last years, interest in the results of these quantitative analyses increases again, particularly in connection with the researches of the behaviour of commodity prices, see Deaton and Laroque (1992), Helmberger and Chavas (1996), Caucutt et al. (1999), Levy (2007), Colman and Miah (2008), Adjemian, and Smith (2012) etc. The specifications and applications of the models have to respect the technical and economical linkages of the partial markets within the studied commodity verticals, see Cramer and Jensen (1994), Mohanty et al. (1995) or Dutta et al (2002). The demand system within the commodity vertical is based on the final consumer demand - primary demand function. The primary function for the supply system within the commodity vertical is the supply on the market for the primal raw, see Cramer and Jensen (1994). The explorations of the consumer demand for the final food and the farmer supply of the agricultural commodity are thus determinative and without substitution for the complete economic researches of the commodity vertical within agricultural-food sector. This paper will be focused on the supply on the Czech wheat market. Studies and analyses in the area of commodity supply within the Czech foodagricultural sector are relatively infrequent. For this reason, it is not possible to adequately discuss and compare the achieved results and findings from this performed analysis. On the other hand, a small number of these economic studies within the Czech Republic underline the need of their performing, particularly in the field of the important agricultural commodities just as wheat.

Economic theories state that supplied quantity of the agricultural commodity is affected by many factors, see Maurice and Phillips (1992). The supply volume of agricultural commodity is 
especially depended on the own price of the given commodity, prices of related commodities, price of inputs, number of the commodity suppliers, number of the commodity purchasers, government policies and regulations, but also weather. For the purposes of the quantitative-economic analysis of the commodity vertical, the supply functions within the vertical supply system are primarily investigated from the viewpoint of the relationships between the own price of the commodity $(P)$ and the supply quantity of the commodity $(S Q)$. These simplifications of the market supply functions are rigorously subordinate to the principle of ceteris paribus. The price-supply functions can be formulated as $S Q=f(P)$ or as $P=f^{-1}(S Q)$, thus in inverse form, see Carlton, and Perloff (1994). The inverse specification of the supply function is very useful specifically for the explanation of the price behaviour on the agricultural commodity markets in relation to the changes in market supply. We can determine and evaluate the value of pricesupply flexibility for the given commodity market. With the help of inverse supply function, we can also estimate the price-supply elasticity, but these reciprocal estimations have certain limitations and are not entirely accurate, see articles of Houck (1965) and (1966) or Huang (1996).

The aim of this paper is estimation and evaluation of the price-supply flexibility on the Czech market for food-quality wheat in the time period 19952011. The data from the Situation and Perspective Report about wheat (Ministry of Agriculture of the Czech Republic) and data from the Czech Statistical Office were used for the purpose of this analysis. For estimations of the price-supply flexibility, the inverse specification of the supply function was applied. The inverse supply model was based on the double log-linear construction. The parameters of the given model were estimated using OLS HAC method. The developed model of the supply function in the Czech market for food quality wheat was statistically tested: t-tests of its parameters, F-test of multiple determination index, and ADF-tests of unit root of the regression residues. Within statistical verification of the developed supply model, the coefficient of the first order autocorrelation was determined and Durbin-Watson statistics was tested. In studied period, the ordinary and dynamic price flexibility of the wheat supply on the Czech market was calculated and evaluated by means of the estimated regression model.

\section{DATA AND METHODS}

For the analysis of the price-supply flexibility of the Czech market for wheat in 1995-2011, the database from the Situation and perspective report about wheat was used. From this commodity report published by the Czech Ministry of Agriculture, time series of the annual levels of the wheat production in the Czech Republic $\left(D P Q_{t}\right)$, wheat import to the Czech Republic $\left(I M Q_{t}\right)$ and wheat reserve (wheat stock) of the Czech Republic $\left(R Q_{t}\right)$ were received. The year values of the production, import and stock were recorded in thousands of tons.

Within the performed analysis, the total annual level of the supply on the Czech market for wheat was defined as the sum of the domestic wheat production in year $t\left(D P Q_{t}\right)$ and wheat import to the Czech Republic in year $t\left(I M Q_{t}\right)$ :

$S Q_{t}=D P Q_{t}+I M Q_{t}$.

The volume of the wheat reserve (stock) in the Czech Republic in the given year is a key for the dynamics of the studied supply function, because $R Q_{t}$ reflects the excess of supply on the commodity market for wheat in the previous year $\left(E S Q_{t-1}\right)$, thus a positive value of the difference between the commodity supply and commodity demand in the previous period:

$$
E S Q_{t-1}=S Q_{t-1}-D Q_{t-1}
$$

The volume of the wheat stock in the Czech Republic in year $t$ is, however, also depended on its level before last year $\left(R Q_{\mathrm{t}-2}\right)$. Thus, the Czech wheat stock in the given year $t$ can be extended to the next sum:

$R Q_{\mathrm{t}}=E S Q_{t-1}+R Q_{\mathrm{t}-2}$.

The market prices of food quality wheat constituted the second data set, which was used for the analysis of price-supply flexibility. From the Czech Statistical Office - Publication 7-Price (w7006), the time series of monthly market prices of food quality wheat is received. With regard to the time harmonization within the compiled database, the achieved time series of the monthly wheat prices was aggregated to the annual level. For this purpose, the arithmetic average was applied. Moreover, the use of the average year levels of the wheat market prices removed the seasonal oscillations in the original time series of the month prices. The average year prices of food quality wheat $\left(P_{t}\right)$ were observed in the CZK per tonne.

For the price analysis of the supply function in the Czech market for food quality wheat, more precisely for the analysis of the price-supply flexibility, the log-linear model of the inverse supply function was developed:

$\ln P_{t}=A+B \times \ln S Q_{t}+C \times \ln R Q_{t}+e_{t^{*}}$

In connection with the declaration of variable $R Q_{t}$, see relationships (2) and (3), the supply model (4) can be written in dynamic form (5):

$\ln P_{t}=A+B \times \ln S Q_{t}+C \times \ln \left[E S Q_{t-1}+R Q_{t-2}\right]+e_{t}$.

Double log-linear specification for the regression model of the inverse supply was selected in accordance with the frequently used constructions of models in this research area, see 
for instance Colman and Miah (2008) or Adjemian and Smith (2012). Definition of the lag structure of the explanatory variables in the model was subordinated to its easy application in the estimation and evaluation of the price-supply flexibility of the wheat on the Czech market and it is also based on the results of author's previous research, see Syrovátka (2009). The possibilities of available databases (length of the time series) naturally determined the lag structure in the regression model of wheatsupply, too.

The values of parameters $A, B, C$ in the dynamic model of inverse supply (5) were obtained using the methods of Ordinary Least Squares with the robust standard error respecting the possibility of heteroscedasticity and autocorrelation (OLSHAC estimates), see Andrews and Monahan (1992). The statistical significance of the achieved regression parameters was examined on the basis of t-tests: $t_{A} \wedge \alpha\left|t_{A}\right|, t_{B} \wedge \alpha\left|t_{B}\right|, t_{C} \wedge \alpha\left|t_{C}\right|$. The statistical verification of the regression model of the market supply for food quality wheat continued by the calculation of multiple determination index $\left(R^{2}\right)$. F-test was used for the statistical verification of the value multiple determination. Due to the nature of the used database - time series, the statistical verification of created supply model was also focused on the time series stationarity of achieved residues (et), see Hušek (1999) or Arlt (1999). The stationarity of time series $e_{t}$ was examined through $\tau$-test, see ADF-tests of unit root by Dickey and Fuller (1981). ADF-test of the unit root $(a=1)$ of time series $e_{t}$ was based on the autoregressive model without constant and deterministic trend. Given the length of time series $e_{t}(T=17)$, we could theoretically consider the seven years lag as the maximum lag in the autoregressive model. However, the testing of the maximum lag (built-in procedure of used software - Gretl) has shown that autoregressive scheme of the first order is sufficient for ADF-test of achieved regression residues, which is confirmed by the results of Deaton and Laroque (1992), or in the Czech wheat market, the author's results, Syrovátka (2009). Thus, resulting specification of the used autoregressive model was as follows:

$\Delta e_{t}=(a-1) \times e_{t-1}+a_{1} \times \Delta e_{t-1}+u_{t}$.

Within investigation of the regression residues $\left(e_{+}\right)$, the coefficient of autocorrelation of lag $1(\rho)$ was determined and evaluated. Statistical significance of the first order autocorrelation of $e_{t}$ was tested through Durbin-Watson statistics (d).

Based on statistically verified econometric model (5), the ordinary price flexibility of the wheat supply on the Czech market was primarily evaluated, thus the flexibility coefficient was derived:

$\phi_{s}=\left(\delta P_{t} / \delta S Q_{t}\right) \times\left(P_{t} / S Q_{t}\right)$.

In the case of log-linear specification of the econometric model of the inverse supply function, the determination of the coefficient of ordinary price-supply flexibility was very simple, because this mathematical construction implied:

$\phi_{S}=B$

The dynamic nature of the developed model of inverse supply function, see its specification (5), allowed us also to find the dynamic pricesupply flexibility of the first order. This dynamic price-supply flexibility, thus more precisely price flexibility of the supply excess in previous year, was evaluated through the coefficient:

$\phi_{E S}=\frac{\delta P_{t}}{\delta\left(E S Q_{t-1}+R Q_{t-2}\right)} \times \frac{\left(E S Q_{t-1}+R Q_{t-2}\right)}{P_{t}}$.

The coefficient $\phi_{\mathrm{ES}}$ (9) was again very simple to determine within the log-linear specification of supply model (5):

$\phi_{E S}=C$.

From the viewpoint of the economic theory, see Adjemian and Smith (2012), the coefficient of dynamic price-supply flexibility of the fires order (10) reflects the intensity of the price equalization process on the Czech market for food quality wheat.

Determined coefficients of the price flexibility (8) and (10) were also used for the economical verification of the estimated regression model (5). According to Law of increasing supply: $(\Delta P / \triangle S Q)>0$ and functioning of Price equalization process: $S Q>D Q \Rightarrow \Delta P<0$, see Maurice and Phillips (1992), it must be fulfilled, that:

$\phi_{S}>0$

$\phi_{E S}<0$.

All statistical estimates and tests were computed in Gretl 1.9.11.

\section{RESULTS, FINDINGS AND DISCUSSION}

Using the annual data about the supply of food quality wheat in the Czech Republic $\left(S Q_{t}\right)$, annual data about stocks in the Czech Republic $\left(R Q_{t}\right)$ and annual data about the market wheat prices of $\left(P_{t}\right)$ in the time period from 1995 to 2011, the dynamic model of inverse supply function was developed in connection with the described methodology. Obtained OLS-HAC estimates of the parameters in the log-linear supply model (5) and the results of its statistical verification are summarized in Tab. I.

Tab. I shows that the estimated log-linear model of the inverse supply function in the Czech wheat market is in principle statistically acceptable. According to ADF-test, the regression supply model generates the time series of the residues $\left(e_{t}\right)$ that has a stationary character: $e_{+} \sim \mathrm{I}(0)$, see Arlt (1999). The significance level $\alpha$ of $\tau$-statistics of the unit roots is less than $0.001 \%$. The level of the first order autocorrelation within the time series of regression 
I: Parameters and statistical verification of regression supply model

\begin{tabular}{|c|c|c|c|c|}
\hline \multicolumn{5}{|c|}{$\ln P_{t}=\mathrm{A}+\mathrm{B} \times \ln S Q_{t}+C \times \ln \left[E S Q_{t-1}+R Q_{t-2}\right]+e_{t}$} \\
\hline parameter & OLS-HAC estimation & standard error & t-statistic & significance level \\
\hline$A$ & +6.7873 & 2.3499 & $t_{A}=2.8884$ & $\alpha\left|t_{A}\right|=1.1910 \times 10^{-2}$ \\
\hline B & +0.3492 & 0.2620 & $t_{B}=1.33262$ & $\alpha\left|t_{B}\right|=0.2040$ \\
\hline C & -0.2210 & $8.2474 \times 10^{-2}$ & $t_{C}=-2.6799$ & $\alpha\left|t_{C}\right|=1.7950 \times 10^{-2}$ \\
\hline \multicolumn{3}{|c|}{ multiple determination } & \multicolumn{2}{|l|}{$R^{2}=0.2217$} \\
\hline \multicolumn{2}{|c|}{ F-test of multiple determination } & \multicolumn{3}{|c|}{$F(2 ; 14)=5.5899 \wedge \alpha|F|=1.6426 \times 10^{-2}$} \\
\hline \multicolumn{2}{|c|}{ Durbin-Watson statistics } & \multicolumn{3}{|c|}{$d=1.6969$} \\
\hline \multicolumn{2}{|c|}{$\begin{array}{l}\text { coefficient of autocorrelation of the first } \\
\text { order (lag 1) }\end{array}$} & \multicolumn{3}{|c|}{$\rho=0.033$} \\
\hline \multicolumn{5}{|c|}{ ADF test: $\Delta e_{t}=(\alpha-1) \times e_{t-1}+\alpha_{1} \times \Delta e_{t-1}+u_{t}$} \\
\hline \multicolumn{2}{|c|}{ estimation of unit root: } & \multirow{2}{*}{$\tau$-statistic: } & \multicolumn{2}{|c|}{ asymptotic significance level of $\tau$-test: } \\
\hline \multicolumn{2}{|c|}{$(\alpha-1)=-1.6604$} & & \multicolumn{2}{|c|}{$\alpha|\tau|=8.288 \times 10^{-9}$} \\
\hline
\end{tabular}

Source: author's calculation

residues $(\rho$,$) , reached a low value, only 3.3\%. Durbin-$ Watson test confirmed that obtained value of this autocorrelation within the time series $e_{t}$ is not statistically significant. Satisfactory results were also received within $t$-tests of the regression parameters $A$ and $C$. The values of both of these parameters were statistically significant more than $98 \%$. The estimated value of parameter $B$ was statistically significant only at $79 \%$. However, the developed econometric model of the market wheat supply can be identified as statistically significant regression. This confirms the results of $F$-test of $R^{2}$. The significance level of $F$-test was less than $2 \%(\alpha|F|=1.64 \%)$. The multipledetermination index of this regression achieved did not reach a too high size. $R^{2}$ achieved only the value of $22.17 \%$. Thus, the supply level on the Czech wheat market in the given year and supply excess in the previous year determine the wheat market prices in the Czech Republic by only $22 \%$. This implies that other factors affect the price level on the Czech wheat market with intensity of $78 \%$, which confirm the studies of the vertical and horizontal price transmissions, see Cramer and Jensen, (1994), Mohanty et al (1995) or Helmberger and Chavas (1996) etc. The dynamic log-linear model inverse supply function estimated for the Czech commodity market for food quality wheat is also acceptable from the viewpoint of the economic theory, because its parameters $B=+0.3492$ and $C=-0.2210$ satisfy: $B>0 \wedge C<0$. The developed supply model respects the Law of increasing supply (11.1) and functioning Price equalization process (11.2).

After statistic and economic verification, the developed regression model was applied to the analysis of the price flexibility of the supply on the Czech commodity market for the food quality wheat in the years 1995-2011. The level of ordinary pricesupply flexibility (7): $\phi_{S}=\left(\delta P_{t} / \delta S Q_{t}\right) \times\left(P_{t} / S Q_{t}\right)$ and dynamic price-supply flexibility of the first order (9): $\phi_{E S}=\left(\delta P_{t} / \delta\left(E S Q_{t-1}+R Q_{t-2}\right)\right) \times\left(\left(E S Q_{t-1}+R Q_{t-2}\right) / P_{t}\right)$ were calculated and evaluated. In the case of loglinear construction of the used supply model, the calculation of the value of ordinary and dynamic price-supply flexibility was very easy, because the equations (8) and (10) are hold in the log-linear model, thus: $\phi_{S}=B \wedge \phi_{E S}=C$.

In accordance with the value of the coefficient of ordinary price-supply flexibility (8), we can conclude that a one percent increase in the Czech wheat supply in a given year generates the growth of the wheat price on the Czech commodity market by $0.3492 \%$ in same year. Thus in the studied period (1995-2011), the reactions of wheat price to changes in the quantity supplied on the Czech wheat market were not flexible. Means (1972) explains the inflexible behaviour of the market prices within a time period as a result of the existence of institutions and their working on given market administrated prices theory. The concept of Means's theory of administrated prices can be used to explain the low level of price flexibility of the commodity market, if any subject determines the transaction price for the given market and time period. This price level is not, however, determined by actual interaction of the supply and demand in the market and it is fixed for a certain time period. Within the commodity markets, the state may have an interest ${ }^{1}$ to fix the price level for some commodities depending on their strategic importance for the country. In the Czech Republic, wheat belongs to the important agricultural commodities. The Czech Government $^{2}$ intervenes on the domestic wheat market through government purchases or sales from the state reserves. In case of the purchases, the intervention price is paid to the wheat producer. These governments' interventions into the wheat 
market equilibrium or into wheat price level are not usually and/or regularly realized. Thus, we cannot speak about any price fixing within the Czech wheat market.

Price inflexibility on the commodity market may also be associated with signing of the long-term contracts (valid for several years) or with the future contracts (guaranteed fixed price for sales/purchase). In practise, the Czech agricultural producers do not sufficiently exploit these business-law instruments for their hedging. Thus, we fail to explain the low level of price-supply flexibility on the Czech wheat market. This fact is partially (indirectly) reflected in the low value of estimated parameter $C$, whose one year value lagged price-supply flexibility. Interpretation of this dynamic price flexibility of supply on the Czech wheat market will be more discussed later in this article.

Many economists explain the low flexibility of the market prices in the context of market structure or industry organisation, see Levy (2007). The relation between market structure and price flexibility is evident in case of monopoly market. Using the monopoly equilibrium, we can derive the relationship: $P=M C /[1+\phi]$, for more details see Varian (2010). The oligopoly with the kinked demand represents the next demonstration of the relationship between market structure and flexibility of the market prices; see Maurice and Phillips (1992). Generally, market prices in the more concentrated industries descent significantly less than those in the industries with the strong competition among suppliers; see Caucutt et al (1999). In the Czech Republic, the agricultural producers form relatively strong competitive environment on the supply side of the wheat market, while buying subjects (Agrofert holdings a.s., Agropol Goup a.s.) have relatively high level of monopoly power. Thus, from the viewpoint of the outlined market structure, the Czech wheat market tends to the inflexible price reactions in relation to changes in the market supply.

Developed regression model (5) also allowed the dynamic evaluation of the price-supply flexibility within the Czech market for food quality wheat. More precisely, the supply model allowed the estimation of the price flexibility in relation to the excess supply in the previous year. The coefficient of dynamic price-supply flexibility of the first order is equal to the parameter $\mathrm{C}$, see relationship (10). In according with the estimated value of this flexibility coefficient, we can conclude that a one percent increase in the excess supply on the Czech wheat market in the given year brings the fall of the wheat market price by $0.2210 \%$ in following year. This result also suggests that behaviour of the wheat market prices is inflexible to the changes in the excess wheat supply in the year before. Thus, the price-equalization process on this Czech wheat market works more slowly.

Some economic articles, primarily Houck (1965), show that achieved coefficients of the price flexibility are possible to use for the estimations the price elasticity. Under certain conditions (ceteris paribus estimation of price-supply function), the mutual inverse relationship between the coefficient of price-supply elasticity $\left(\epsilon_{\mathrm{s}}\right)$ and the coefficient of price-supply flexibility $\left(\phi_{\mathrm{S}}\right)$ is held, thus: $\epsilon_{\mathrm{S}} \tilde{=} \mathrm{l} /$ $\phi_{s}$; see Houck (1965). In practise, ceteris paribus estimation of the inverse supply function is almost insurmountable restriction for outlined priceelasticity evaluations; see Houck (1966) or Huang (1996). In accordance with the inverse value of the coefficient of ordinary price-supply flexibility (8), we can conclude that wheat supply reacts elastically, because $1 \%$ increase of the wheat price on the Czech commodity market raises the supplied wheat volume by $2.8640 \%$.

Although evaluations of the price-supply flexibility in the Czech wheat market are not too frequent (basically none), and all results from this fields are very valuable, we have to remember some limitations of the reported results. First, the used log-linear model can simulate only and only a constant level of the price-supply flexibility and thus also only and only the constant level of the price-supply elasticity. This constancy of the pricesupply flexibility or elasticity is contrary to the ordinary shape of the commodity supply curve, especially when evaluated within the large changes in supplied quantity or commodity price. Second, the level of price-supply flexibility and elasticity is the result of other factors, which the developed supply model did not include. It is confirmed by the attained low value of multiple-determination ratio (22.17\%). Third, the attained estimations of price-supply flexibility and elasticity are negatively affected by very short time series in available dataset $(T=17)$, therefore the realised research did not even try to distinguish between the long-term and shortterm level of the price-supply flexibility or pricesupply elasticity. In the case of longer time series, it is then possible to apply the Error Correction Models, see Hušek (1999) or Arlt (1999).

\section{SUMMARY}

The paper explores the price-supply flexibility of the Czech commodity market for food quality wheat in 1995-2011. For this analysis, inversion definition of the supply function was applied. The model of the inverse supply function in the Czech wheat market was based on the log-linear specification: $\ln P t=6.7874+0.3492 \times \ln S Q_{t}-0,2210 \times \ln \left[E S Q_{t-1}+R Q_{t-2}\right]+e_{t}$. Parameters of the given supply model were estimated using OLS-HAC method. The developed regression model of the supply function was statistically tested: t-tests of its parameters, F-test of determination index, and ADF-tests of unit roots. Within statistical verification of the supply model, the coefficient of the first order autocorrelation 
was determined and Durbin-Watson statistics was tested. Ordinary and dynamic price flexibility of the wheat supply on the Czech commodity market was determined in relation to the parameters of the developed supply model. In accordance with the estimations, the ordinary price-supply flexibility achieved $+0.3492 \%$ and the dynamic price-supply flexibility of the first order was $-0.2210 \%$. In accordance with the coefficient of the ordinary price-supply flexibility, a one percent increase in the Czech wheat supply in a given year generates the growth of the wheat market price approximately by $0.35 \%$ in the same year. In the studied period, the price reactions on the Czech wheat market are inflexible. In according with the coefficient of dynamic price-supply flexibility of the first order, a one percent increase in the supply excess on the Czech wheat market in the given year brings the fall of the market wheat price approximately by $0.22 \%$ in following year. The price-equalization process on the Czech wheat market is also inflexible. Within the interpretation of both estimated coefficients of the price-supply flexibility, the multi-factor nature of the commodity supply function must be respected. Moreover, it is also important to distinguish the short-term and long-term periods within the evaluation of the price-supply flexibility.

\section{Acknowledgement}

The paper was prepared within the Research Project of Mendel University in Brno, MSM 6215648904, Czech Economy in Integration and Globalisation Processes and Development of the Agricultural Sector and Services Sector under the New Conditions of the Integrated Agrarian Market as a Part of Solving the Thematic Specialisation 4 "Development Trends in Agribusiness, Formation of Segmented Markets within Commodity Chains and Food Networks in the Process of Integration and Globalisation and Change of Agrarian Policy".

\section{REFERENCES}

ADAMS, F. G., BEHRMAN, J. R., 1976: Econometric models of world agricultural commodity markets. Cocoa, coffee, tea, wool, cotton, sugar, wheat, rice. Cambridge: Ballinger, 160 p. ISBN 0-88410-290-4.

ADJEMIAN, M. K., SMITH A., 2012: Using USDA Forecasts to Estimate the Price Flexibility of Demand for Agricultural Commodities. Am. J. Agr. Econ., 94, 4: 978-995. ISSN 0002-9092.

ANDREWS, D. W. K., MONAHAN, J. C., 1992: An improved heteroskedasticity and autocorrelation consistent covariance matrix estimator. Econometrica, 60, 4: 953-966. ISSN 00129682, E-ISSN 14680262.

ARLT, J., 1999: Moderní metody modelování ekonomických časových rad. 1. vyd. Praha: Grada Publishing, 312 s. ISBN 80-7169-539-4.

CARLTON, D. W., PERLOFF, J. M., 1994: Modern Industrial Organization. Second Edition. New York: Harper Collins College Publishers, 973 p. ISBN 0-673-46902-6.

CAUCUTT, E. M., GHOSH, M., KELTON, CH. M. L., 1999: Durability Versus Concentration as an Explanation for Price Inflexibility. Review of Industrial Organization, 14, 1: 27-50. ISSN 0889938X (Print) 1573-7160 (Online).

COLMAN, D., MIAH, H., 2008: On Some Estimates of Price Flexibilities for Meat and Their Interpretation. Journal of Agricultural Economics, 24, 2: 353-368. ISSN 1477-9552.

CRAMER, G. L., JENSEN, C. W., 1994: Agricultural Economics and Agribusiness. USA: John Wiley \& Sons, p. 534. ISBN 0-471-59552-7.

DEATON, A., LAROQUE, G., 1992: On the Behavior of Commodity Prices. Review of Economic Studies, 59, l: 1-23. ISSN 0034-6527.
DICKEY, D. A., FULLER, W. A., 1981: Likelihood Ratio Statistics for Autoregressive Time Series with a Unit Root. Econometrica, 49, 4: 1057-1072. ISSN 00129682.

DUTTA, S., BERGEN, M. E. and LEVY, D., 2002: Price Flexibility in Channels of Distribution: Evidence from Scanner Data. Journal of Economic Dynamics and Control, 26, 11: 1845-1900. ISSN 0165-1889.

HELMBERGER, P. G., CHAVAS, J. P., 1996: The Economics of Agricultural Prices. New Jersey: Prentice Hall, 356 p. ISBN 0-13-372640-1.

HOUCK, J. P., 1965: The Relationship of Direct Price Flexibilities to Direct Price Elasticities. Journal of Farm Economics, 47, 3: 789-792. ISSN 10711031.

HOUCK, J. P., 1966: A Look at Flexibilities and Elasticities. Journal of Farm Economics, 48, 2: 225232. ISSN 10711031.

HUANG, K. S., 1996: A Further Look at Flexibilities and Elasticities: Reply. American Journal of Agricultural Economics, 78, 4: 1130-1131. Online ISSN 1467-8276.

HUŠEK, R., 1999: Ekonometrická analýza. 1. vyd. Praha: Ekopress, 303 s. ISBN 80-86119-19-X.

LEVY, D., 2007: Price Rigidity and Flexibility: Recent Theoretical Developments. Manage. Decis. Econ., 28, 6: 523-530. Online ISSN 1099-1468.

MAURICE, S. Ch., PHILLIPS, O. R., 1992: Economic Analysis, Theory and Application. 6th ed. Boston: Irwin, 738 p. ISBN 0-256-08209-X.

MEANS, G. C., 1972: The Administered-Price Thesis Reconfirmed. The American Economic Review, 62, 3: 292-306. ISSN 0002-8282.

MOHANTY, S., PETERSON, E. W. F, KRUSE, N. C., 1995: Price Asymmetry in the International Wheat Market, Canadian Journal of Agricultural Economics, 43, 3: 355-366. Online ISSN 1744-7976. 
SYROVÁTKA, P., 2009: Stacionarita časové řady cen potravinářské pšenice. In: Ekonomika zdroju českého zemédèlstvi a jejich efektivní využívání v rámci zemédèlskopotravinárských systémů. Praha: ČZU PEF, 2009, s. 135-143. ISBN 978-80-213-2011-6.
VARIAN, H. R., 2010: Intermediate Microeconomics: AModern Approach. 8th ed., New York: W. W. Norton \& Company, 739 p. ISBN 978-0-393-93424-3.

\section{Address}

doc. Ing. Pavel Syrovátka, Ph.D., Department of Economics, Mendel University in Brno, Zemědělská 1, 61300 Brno, Czech Republic, e-mail: pavels@mendelu.cz 